\title{
NEW DISTRIBUTION AND SPECIES RECORDS OF TRICHOPTERA FROM SOUTHERN AND SOUTHEASTERN BRAZIL
}

\author{
Roger J. Blahnik, Henrique Paprocki, and Ralph W. Holzenthal
}

Biota Neotropica v4 (n1) - http://www.biotaneotropica.org.br/v4n1/pt/abstract?inventory+BN01304012004

\author{
Date Received 10/02/2003 \\ Accepted 03/12/2004
}
Department of Entomology, University of Minnesota
1980 Folwell Ave, Saint Paul, MN, 55108, USA
email:blah003@umn.edu

\begin{abstract}
We provide here a list of new species records of Trichoptera (Insecta) collected in Southern and Southeastern Brazil. We report 21 new distribution records for the country of Brazil. We also provide new distribution records for 92 species of Trichoptera for the states of Minas Gerais, São Paulo, Rio de Janeiro, Paraná and Santa Catarina.
\end{abstract}

Key words: Trichoptera, Caddisflies, Checklist, Aquatic Insects, Neotropical, Brazil, Distribution, New records

\section{Resumo}

Apresenta-se aqui uma lista de novos registros de Trichoptera (Insecta) para estados do Sul e Sudeste do Brasil. O número de novos registros de espécies de Trichoptera apresentados aqui é de 92, sendo que 21 são novos registros também para país.

Palavras-chave:Trichoptera, Fauna, Lista de espécies, Brasil, Insetos aquáticos, Distribuição

http://www.biotaneotropica.org.br 


\section{Introduction}

The diversity and distribution of Trichoptera from the Neotropical region is still very incompletely known; many new species remain to be discovered and described and most described species are known only from fragmentary distribution records. Although several regions in the Neotropics have been reasonably well surveyed (e.g., the Caribbean, Costa Rica, Chile), most distribution records of species of Trichoptera outside these regions are still represented by incidental collections. Many species are still only known from the site from which the species was originally described. The accompanying list was compiled from recent collections made during a United States National Science Foundation funded project, conducted in coordination with the Museu de Zoologia, Universidade de São Paulo, to inventory and describe the Trichoptera diversity of southeastern Brazil. It represents new distribution records of Trichoptera by state for the collection survey area. To date, however, no collecting has been done in the state of Espírito Santo. Records from the states of Santa Catarina and Paraná in southern Brazil resulted from collecting done by Ralph Holzenthal during a sabbatical prior to the initiation of the research project. For a complete list of the taxa currently known from Brazil, including state records, the reader is referred to the accompanying article by Paprocki et al. (2004). In addition to these records of previously described species, many species (about half of the total collected) represent new and undescribed species. Taxonomic and systematic work on these are in progress and descriptions will be reported in subsequent papers. The primary purpose of this paper is to list new species and distribution records by state from the inventory survey project. Although, the primary value of the list is to add to the knowledge of the Trichoptera fauna of southern and southeastern Brazil itself, the list has the further value of helping to fill continent-wide gaps in our knowledge of Trichoptera distribution in South America.

\section{Collecting Methods}

Collections of insects result from the juxtaposition of three elements: time, place, and opportunity. In order for a species of insect to be collected, a collector must be in the right place, at the right time, and s/he must also have or take the opportunity to collect. Needless to say, the inventory discussed here and in the accompanying article by Paprocki et al. (2004) allowed for the juxtaposition of these elements for only some fraction of the Trichoptera fauna actually present in southern and southeastern Brazil. Undoubtedly, many additional species remain to be collected. The following description of collecting methods is given both to record the methods used during the inventory and as an aid to students interesting in documenting the fauna.

A standard method of collecting Trichoptera is the use of a blacklight (ultra-violet light) and bed sheet erected near a stream. Primary flight time of caddisflies begins about sunset and continues for several hours after dark, but rapidly tapers off in the later evening. A second flight period occurs near dawn for some species. A 12 volt automobile battery, which can be recharged as necessary, provides enough energy to run a blacklight for several nights. However, use of a portable generator allows the possibility of also running a mercury vapor light, which gives off a much brighter light. Simultaneous use of both a mercury vapor light and blacklight maximizes their effectiveness. A tarp suspended over the sheet will provide essential protection from rain and keep the sheet dry. With such a precaution, flight of caddisflies to the sheet will continue during mild or even moderate rainfall, and it is possible to continue collecting. The best and most effective way to collect caddisflies is directly from the sheet with use of cyanide jars. If tissue paper is placed in the bottom of the jar and the jar is not allowed to become too full of insects, the hairs on the wings of the specimens, which are easily removed using general collection techniques or by rough or careless handling, will be retained. The hairs on the wings, much like the scales on the wings of Lepidoptera, are very useful diagnostic characters (Holzenthal and Blahnik 1995). Because the specimens are fragile and desiccate quickly, it is important that they be pinned promptly. Usually all of the specimens collected during a single night can be easily pinned the following morning, using stainless steel pins or minutens. Fortunately, it is not necessary to spread the wings of Trichoptera. While requiring extra effort in the field compared to collecting specimens in ethanol, specimens collected this way are also the most valuable for systematic work. When it is considered that some percentage of specimens collected will likely also constitute type series, the value of carefully pinning them should be evident.

It is also valuable to augment collecting at a sheet with other collecting techniques, including ethanol pan traps, malaise traps suspended across a stream, and day collecting by net. The method we use for ethanol pan traps is simply to place a blacklight horizontally over a shallow white pan, with a small amount of ethanol in the bottom. The trap can be run for several hours after sunset, or all night if conservation of battery power is not an issue. It must be admitted that collecting specimens in ethanol is the preferred method by some (perhaps most) Trichoptera taxonomists. However, while it is possible to do systematic work on specimens stored in ethanol, and even some advantages (more pliability, less shrinkage), they lose their color more rapidly than specimens on pins and their overall condition in ethanol deteriorates over time. Ideally, both methods of preservation should be used. Use of ethanol collecting as 
an adjunct method is especially important for species in the family Hydroptilidae (the so-called microcaddisflies), especially at a site where they are very abundant. This is because "micros" usually appear at a sheet in a pulse shortly after sunset and time limits the number of specimens that can be manually collected at a sheet. Use of an ethanol pan trap guarantees that species that may have been missed at the sheet are still collected. Also, if the traps are run all night they may collect species with unusual flight periods. Although it is necessary to collect hydroptilids in ethanol to capture total diversity, every effort should still be made to collect and pin as many specimens as possible. Malaise traps and day collecting (sweeping) with a net, are useful adjunct collecting methods, especially for collecting dayactive species and those not readily attracted to lights. Some day-active species may be common, but are only rarely or incidentally (or never) collected at lights.

It is important also to collect larval specimens from a site for eventual association with adult material. This is especially true if species-level identifications of larvae are ever to be used for biomonitoring purposes. A traditional method for associating larval and adult material is by use of a "metamorphotype" (Vorhies 1909, Ross 1934, Milne 1938, Ross 1944, Wiggins 1996). It requires the fortuitous collection of a mature pupa, or pharate adult, in which the genitalic characters are already formed. Larval sclerites for most species are retained within the pupal case and form the basis for making associations. Rearing of larvae is also useful, but usually requires controlled laboratory conditions. DNA sequencing techniques also hold the promise of being useful for associating larvae and adults, but limited use of the method has been made so far in Trichoptera. Specimens that are either pinned or collected in ethanol can be directly used for DNA sequencing, but efforts should also be made to collect specimens in fluids especially designed for their suitability for preserving DNA, if the eventual goal is to use the material for this purpose. Whatever method is used to associate larvae and adults, once the identity of a larva is determined, it is likely that morphological characters will continue to be important for making species identifications and constructing keys. Taxonomic progress on larvae will inevitably lag behind that of adults, on which species taxonomy is based.

\section{Results and Discussion}

Twenty-one records are of species previously unreported from Brazil. These are indicated in Table 1 by an asterisk. As might be anticipated, of the 92 species for which new state distribution records are given, the majority were either already known from nearby states in Brazil, or from the neighboring countries of Uruguay, Paraguay, or Argentina. Others, however, were previously only reported from countries distant from the collection area or from very distant areas of Brazil, as for example Oxyethira espinada Holzenthal and Harris and Polyplectropus alleni (Yamamoto), previously only known from Costa Rica, Smicridea palifera Flint, previously only recorded from Venezuela, and Chimarra adamsae Blahnik, previously only known from southern Peru and the Rio Xingu region of Brazil. Previous distribution records would have inferred these species to be restricted and endemic in distribution, but obviously this is not the case. Undoubtedly, many species of Trichoptera will prove to be regionally restricted and endemic, but it is still premature to make these kinds of assessments at this time.

Despite the fact that the region of southern and southeastern Brazil has a long history of occupation and includes the largest cities, universities, and museums in the country, the Trichoptera of the area have remained very poorly known and incompletely documented. Fritz Müller, was one early worker on Trichoptera of the region (with publications during 1879-1921), but there has been no recent tradition of Trichoptera research. This absence of workers largely explains why such a large percentage of the fauna has remained unknown. However, a number of Brazilian students have recently become interested in Trichoptera, in part because of the value of studying the fauna in order to do water quality assessment. They are beginning a new tradition in systematic work on Trichoptera within Brazil and it is anticipated that the fauna will soon be much better known.

\section{Acknowledgements}

We are very grateful to the Brazilian federal agency CAPES (Coordenação de Aperfeiçoamento de Pessoal de Nível Superior) for its financial support to Ralph Holzenthal during a visiting professorship at the Universidade Federal do Paraná in 1997-1998 and to Henrique Paprocki for the $\mathrm{PhD}$ abroad fellowship. We are thankful for the assistance provided by Dr. Carlos Roberto Ferreira Brandão and Dr. Sonia Aparecida Casari from the Museu de Zoologia da Universidade de São Paulo. We are indebted to Edeltrudes Câmara and Luciana Barreto Nascimento from the Museu de História Natural da Pontíficia Universidade Católica de Minas Gerais for all the support and infrastructure provided for the collecting trips. We are also very thankful to Marcelo Coutinho Amarante and Aristides Salgado Guimarães Neto for assistance in the field. This material is based upon work supported by the National Science Foundation Grants No. DEB-9971885 and DEB- 0117772. 


\section{Taxon}

Ecnomidae

* $\quad$ Austrotinodes uruguayensis Angrisano 1994

\section{Glossossomatidae}

Mexitrichia albolineata (Ulmer) 1907

Mexitrichia teutona Mosely 1939

* Protoptila cora Flint 1983

\section{Helicopsychidae}

Helicopsyche (Cochliopsyche) clara (Ulmer) 1905

Helicopsyche (Cochliopsyche) opalescens Flint 1972

* Helicopsyche (Cochliopsyche) lobata Flint 1983

Helicopsyche (Feropsyche) monda Flint 1983

\section{Hydrobiosidae}

Atopsyche (Atopsaura) acahuana Schmid 1989 Atopsyche (Atopsaura) huanapu Schmid 1989 Atopsyche (Atopsaura) huarcu Schmid 1989 Atopsyche (Atopsaura) plancki Marlier 1964 Atopsyche (Atopsaura) sanctipauli Flint 1983 Atopsyche (Atopsaura) zernyi Flint 1974

* Atopsyche (Atopsyche) chirihuana Schmid 1989

* Atopsyche (Atopsyche) erigia Ross 1947

\section{Hydropsychidae}

Blepharopus diaphanus Kolenati 1859 Centromacronema obscurum (Ulmer) 1905 Leptonema bifurcatum Flint et al. 1987 Leptonema sparsum (Ulmer) 1905 Leptonema tridens Mosely 1933 Leptonema trispicatum Flint et al. 1987 Leptonema viridianum Navás 1916 Macronema hageni Banks 1924

Macrostemum ulmeri (Banks) 1913

Smicridea (Rhyacophylax) appendiculata Flint 1972

* Smicridea (Rhyacophylax) dentifera Flint 1983a Smicridea (Rhyacophylax) discalis Flint 1972

* Smicridea (Rhyacophylax) forcipata Flint 1983 Smicridea (Rhyacophylax) iguazu Flint 1983 Smicridea (Rhyacophylax) piraya Flint 1983

* Smicridea (Rhyacophylax) radula Flint 1974 Smicridea (Rhyacophylax) scutellaris Flint 1974 Smicridea (Rhyacophylax) spinulosa Flint 1972 Smicridea (Rhyacophylax) unguiculata Flint 1983 Smicridea (Rhyacophylax) vermiculata Flint 1978 Smicridea (Smicridea) albosignata Ulmer 1907 Smicridea (Smicridea) bivittata (Hagen) 1861

* Smicridea (Smicridea) palifera Flint 1981 Smicridea (Smicridea) paranensis Flint 1983 Synoestroposis grisoli Navás 1924 Synoestroposis pedicillata Ulmer 1905

\section{Hydroptilidae}

Abtrichia antennata Mosely 1939

Abtrichia squamosa Mosely 1939

Anchitrichia duplifurcata Flint 1983

Byrsopteryx abrelata Harris and Holzenthal 1994

\section{New state records}

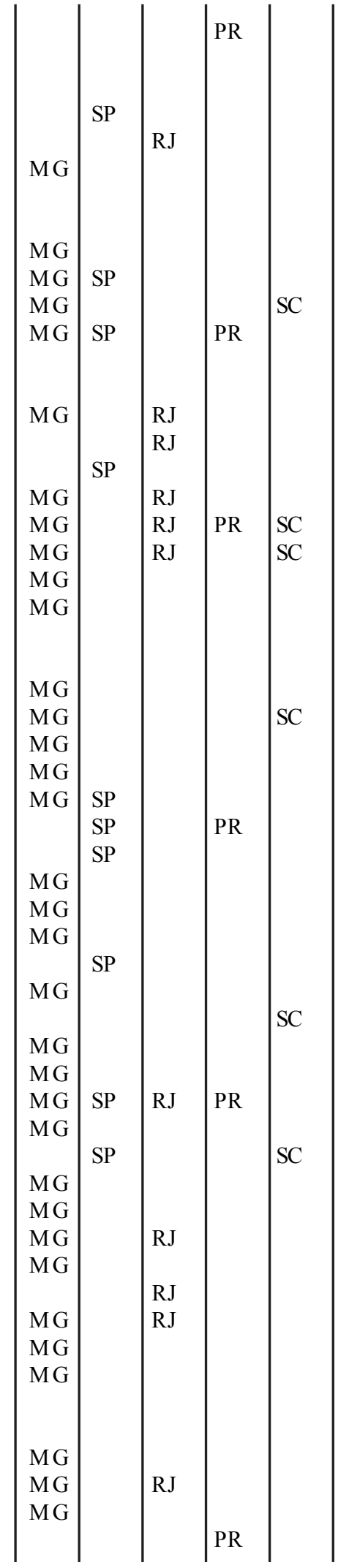


Hydroptila argentinica Flint 1983

* Neotrichia filifera Flint 1983a

* Oxyethira espinada Holzenthal and Harris 1992

* Oxyethira parce (Edwards and Arnold) 1961 Oxyethira tica Holzenthal and Harris 1992 Oxyethira zilaba (Mosely) 1939

\section{Leptoceridae}

Achoropsyche duodecimpunctata (Navás) 1916 Grumichella aequiunguis Flint 1983

Grumichella rostrata Thienemann 1905

Nectopsyche aureovittata Flint 1983

* Nectopsyche acutiloba Flint 1974

Nectopsyche bruchi (Navás) 1920

* Nectopsyche brunneofascia Flint 1983a

Nectopsyche flavofasciata (Ulmer) 1907

Nectopsyche fuscomaculata Flint 1983

Nectopsyche muhni (Navás) 1916

* Nectopsyche navasi Holzenthal 1999

Nectopsyche ortizi Holzenthal 1995

Nectopsyche pantosticta Flint 1983

Nectopsyche punctata (Ulmer) 1905

Nectopsyche separata (Banks) 1920

* Oecetis inconspicua (Walker) 1852

Oecetis iguazu Flint 1983

* Triplectides neotropicus Holzenthal 1988

* $\quad$ Triplectides misionensis Holzenthal 1988

\section{Odontoceridae}

* Marilia elongata Martynov 1912

Marilia major Müller 1880

Marilia minor Müller 1880

* Marilia truncata Flint 1983a

\section{Philopotamidae}

Chimarra (Chimarra) adamsae Blahnik 1998

Chimarra (Chimarrita) camella Blahnik 1997

Chimarra (Chimarrita) camura Blahnik 1997

Chimarra (Curgia) conica Flint 1983

Chimarra (Curgia) froehlichi Flint 1998

Chimarra (Chimarrita) kontilos Blahnik 1997

Chimarra (Chimarrita) majuscula Blahnik 1997

Chimarra (Curgia) teresae Flint 1998

Chimarra (Chimarra) uara Flint 1971

\section{Polycentropodidae}

Cernotina cacha Flint 1971

Cernotina perpendicularis Flint 1971

Cyrnellus fraternus (Banks) 1905

Cyrnellus mammillatus Flint 1971

Cyrnellus risi (Ulmer) 1907

Nyctiophylax neotropicalis Flint 1971

* Polyplectropus alleni (Yamamoto) 1967

\section{Sericostomatidae}

Grumicha grumicha (Vallot) 1855

Total

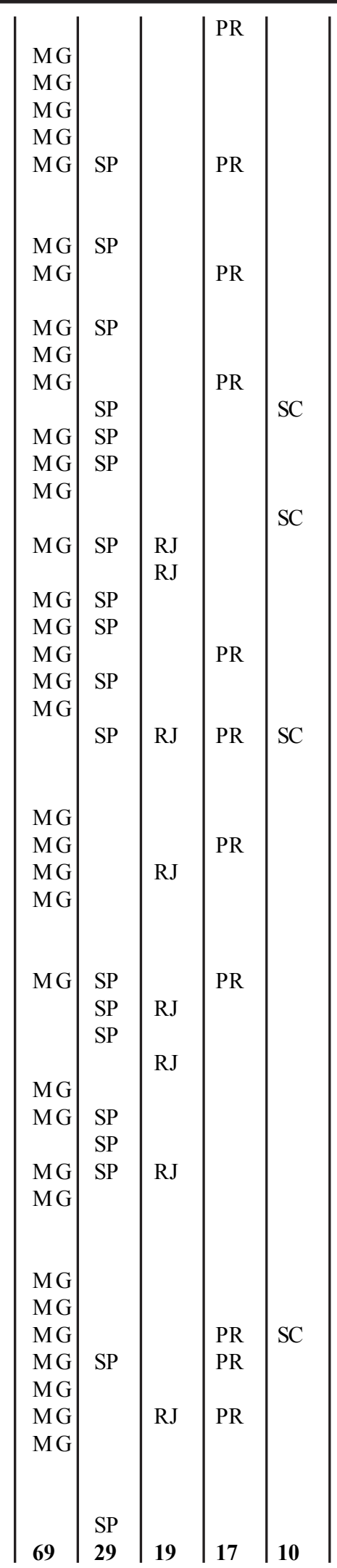

Table 1: New records of Trichoptera Species for the Brazilian States of Minas Gerais, São Paulo, Rio de Janeiro, Paraná and Santa Catarina.

http://www.biotaneotropica.org.br 


\section{Literature Cited}

HOLZENTHAL, R. W. \& . BLAHNIK, R. J. 1995. New Species of Smicridea (Rhyacophylax) (Trichoptera: Hydropsychidae) from Costa Rica. Entomological News 106:213-223.

MILNE, M. J. 1938. The "metamorphotype method" in Trichoptera. Journal of the New York Entomological Society 46: 435-437.

PAPROCKI, H., HOLZENTHAL, R. W. \& BLAHNIK, R.J. 2004. Checklist of Trichoptera (Insecta) of Brazil I. Biota Neotropica 4(1).

ROSS, H. H. 1934. How to Collect and Preserve Insects. Illinois Natural History Survey Circular 2(25): 1-27.

ROSS, H. H. 1944. The Caddisflies or Trichoptera of Illinois. Bulletin of the Illinois Natural History Survey 23(1): 1326.

VORHIES, C. T. 1909. Studies on the Trichoptera of Wisconsin. Transactions of the Wisconsin Academy of Sciences, Arts and Letters 16, Part 1(6): 647-738.

WIGGINS, G. B. 1996. Larvae of the North American Caddisfly Genera (Trichoptera). Toronto, University of Toronto Press.

Title: New Distribution and Species Records of Trichoptera from Southern and Southeastern Brazil

Authors: Roger J. Blahnik, Henrique Paprocki, and Ralph W. Holzenthal

Biota Neotropica, Vol. 4 ( number 1): 2004

http://www.biotaneotropica.org.br/v4n 1/pt/ abstract?inventory+BN01304012004

Date Received 10/02/2003

Accepted 03/12/2004

ISSN 1676-0611

http://www.biotaneotropica.org.br 